\title{
Economic and Environmental Contributions of Declaration of the Marmara Region as Emission Control Area (ECA)
}

\author{
D. Yildırım Peksen*1, G. Alkan ${ }^{2}$ \\ ${ }^{1}$ Maritime and Port Management, Yalova University, Yalova, TURKEY. \\ ${ }^{2}$ Maritime Transportation Management Engineering, Istanbul University, Istanbul, TURKEY
}

\begin{abstract}
Nowadays maritime transport has become an essential part of the international trade due to the massive capacity of carriage of cargoes overseas. In fact that it also impacts to global economy as positively by providing to transport of almost 90 percent of total cargo between countries. On the other hand, air pollution caused by exhausts emissions of ship traffic which is increasing day by day has led to global warming and health problems. This situation has forced the International Maritime Organization (IMO) to bring new regulations. As a result, Annex VI 'Prevention of air pollution from vessels' has been added to 73/78 MARPOL Convention and it brings global and regional limits on $\mathrm{SO}_{\mathrm{x}}$ and $\mathrm{NO}_{\mathrm{x}}$ emissions. Turkey has also adopted above-mentioned annex on 26.02.2013 but not announce any Emission Control Area (ECA) yet. Every year more than 50,000 ships are passing from the Sea of Marmara and the Turkish Straits which are important seaways in international maritime transport and surrounded by the crowded cities about 20 million people. Therefore, it is appear that how human health and environment can be benefited by reducing ship emissions if such a crucial important area as Marmara Region has been announced as ECA.

In this study, amount of total emissions caused by ships will be estimated by comparing released exhaust gases into air in a year before and after ECA proclamation on Marmara Region. In addition, methods to reduce ship emissions according to ECA limits such as alternative fuels and new engine technologies will be discussed. On the other hand, from an economic point of view, external costs of ship emissions on human health and environment will be calculated by using EXIOPOL (A New Environmental Accounting Framework Using Externality Data And Input-Output Tools for Policy Analysis) formula.
\end{abstract}

Keywords: Air pollution, ECA, MARPOL Annex VI, the Sea of Marmara, ship emissions.

\section{INTRODUCTION}

Air pollutants and greenhouse gas emissions from land transportation are going down slightly; on the contrary, those from shipping are going up dramatically. In addition, land transport are mostly domestic, and its exhaust gases affect national air quality, on the other hand air pollution caused by ships has an impact on international air quality due to the characteristic of ship traffics. Thus, in order to make a control mechanism for ships which are sailing at international sea ways, IMO set the regulations to reduce emissions and negative effects of these emissions. Some countries took precautions to minimize ship emissions and proclaimed an emissions control area which surrounds their all seas. By the way, Turkey has also intent to declare an ECA in near future on the Sea of Marmara to protect Marmara Region against to exhaust emission of ships.

This study aims to analyze environmental and economical effects of ship exhaust emissions in Marmara Region in the light of answers of following questions:

- What is the estimated amount of annual emissions caused by ships passing both transit and non-transit through the Marmara Region?

- What would be the estimated amount of annual emissions if these ships use alternative technology and fuel to meet the requirements of ECA?

- How much is the external cost of Turkey for the ships' transit and non-transit passage through the Marmara Region?

- How much would be external cost of Turkey if these ships use alternative technology and fuel to meet the requirements of ECA?

\section{MATERIAL AND METHODS}

In this section, air emission types and their impacts on the environment and human health have been explained, and also according to Regulations under MARPOL Annex VI, suitable and effective alternatives have 
been analyzed to reduce $\mathrm{SO}_{\mathrm{x}}$ and $\mathrm{NO}_{\mathrm{x}}$ emissions for the study area. After estimating emissions amount in different scenarios, the success of alternative technologies and fuels will be found out.

\subsection{Air Pollution from Ships}

The Environmental Protection Agency defined air pollution as the occurrence of the existing gaseous and particulate pollutants in the atmosphere (EPA 2012). Gaseous and particulate emissions related to fuel consumption are important sources to occur air pollution. Figure 1 summarizes these emissions types. Shipping also affects dramatically air pollution via engine combustion and fuel type, especially emissions of particular matter $(\mathrm{PM})$, nitrogen dioxide $\left(\mathrm{NO}_{2}\right)$, carbon monoxide $(\mathrm{CO})$, sulphur dioxide $\left(\mathrm{SO}_{2}\right)$ ( Abusoglu and Kanoglu 2009).

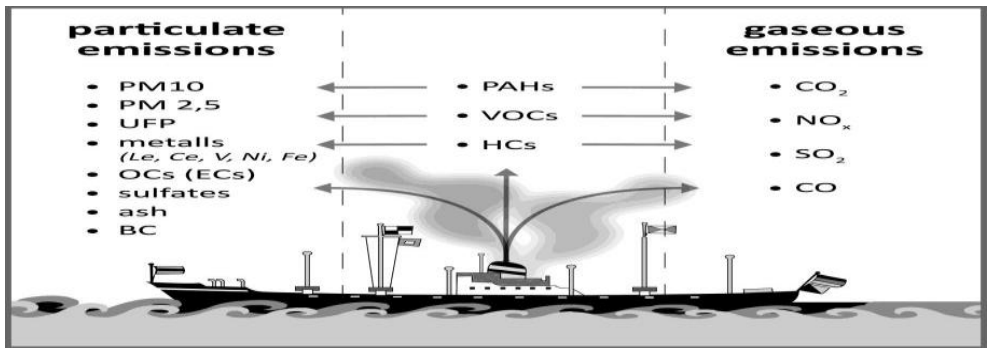

Figure 1. Overview of the ship engine exhausts emissions (Mueller et al. 2011)

There are two main emission types due to combustion of fuel which are air pollutants and greenhouse gases (GHG) (Ling 2011). Air pollutants are defined as chemical substances in the form of soot, smoke, dust, gases, vapor and aerosols which alter the composition of air (T.C. Başbakanlık Mevzuat Bilgi Sistemi 2015). GHG means gases that trap heat in the atmosphere (United States Environmental Protection Agency 2015). These air pollutants and GHG have impact on human health and environment. Figure 2 summarizes these effects as following;

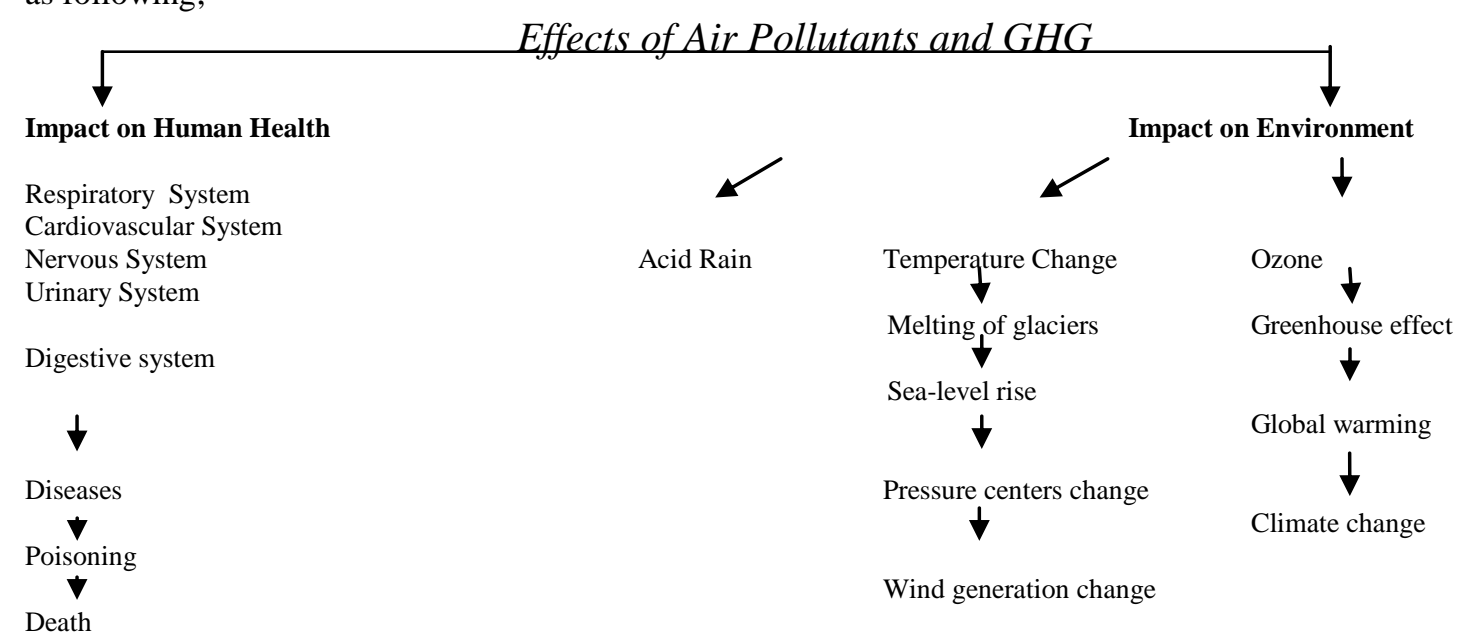

Figure 2. Effects of emissions (Varınca et al.)

Sulphur dioxide $\left(\mathrm{SO}_{2}\right)$, nitrogen oxides $\left(\mathrm{NO}_{\mathrm{x}}\right)$, volatile organic compounds (VOC), particulate matter $(\mathrm{PM})$ and carbon monoxide $(\mathrm{CO})$ are called air pollutants; and carbon dioxide $\left(\mathrm{CO}_{2}\right)$, methane $\left(\mathrm{CH}_{4}\right)$ and nitrous oxide $\left(\mathrm{N}_{2} \mathrm{O}\right)$ are also known as greenhouse gases. Their occurrence depends on fuel type, fuel consumption, engine type, engine power etc. Figure 3 summarizes that how emissions are occurred.

Although shipping is known as a clean transport mode, increasing ship demand makes it a harmful transportation mode for environment because of exhaust emissions. These emissions affect air quality widely because they arise in international waters so IMO has also regulated limits for considerable amount of emissions by ships with the International Convention for the Prevention of Pollution from Ships (MARPOL) (Schrooten et al. 2007). 


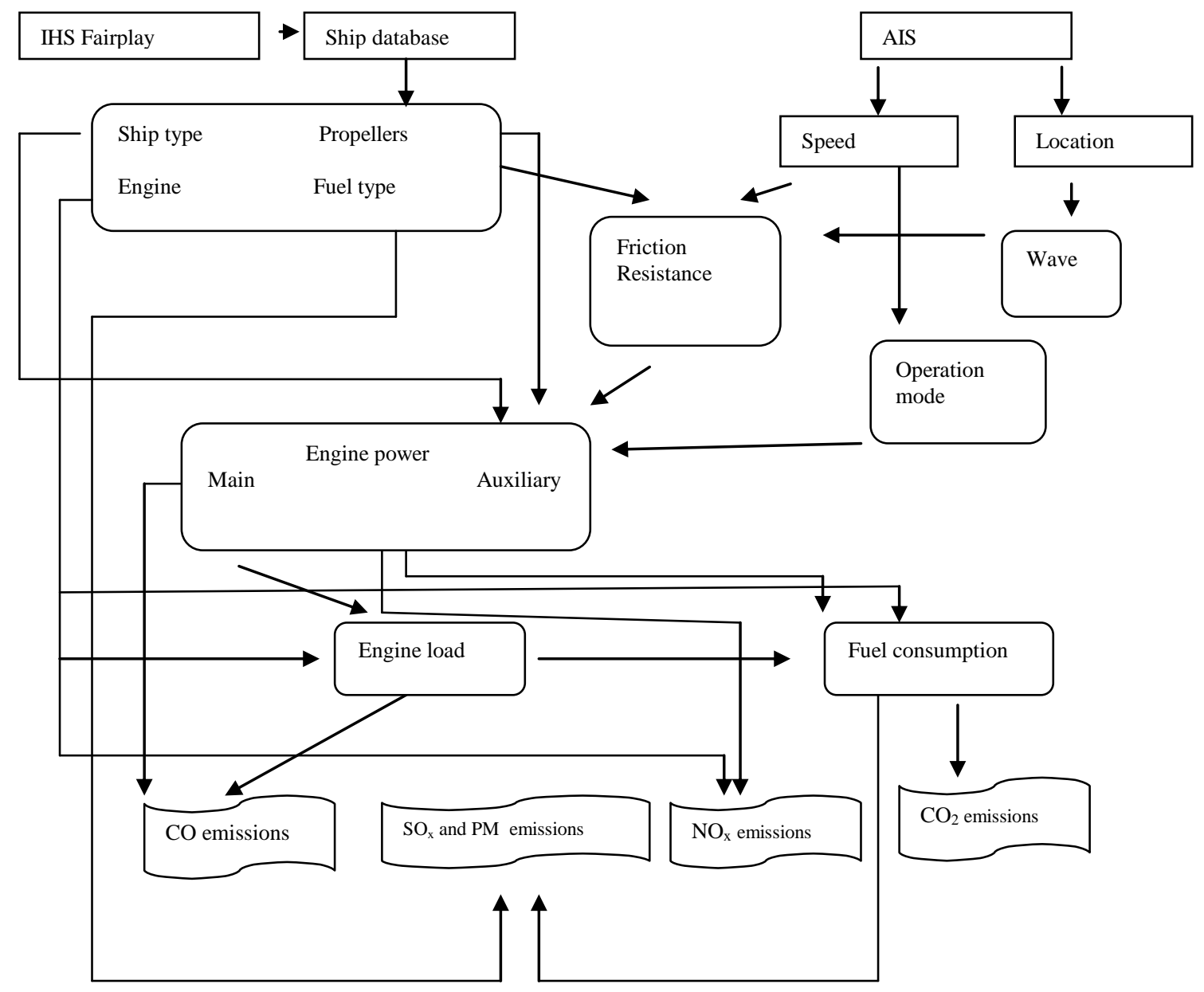

Figure 3. Direct and indirect factors affecting the formation of emissions (Jalkanen).

MARPOL 73/78 as the main convention for preventing of marine pollution from ships includes regulations on various sources of ship-generated pollution within six annexes. One of these annexes, namely Annex VI involves regulation for air pollution of ships, and it is called "Prevention of Air Pollution from Ships" which entered into force in 2005. This annex aims to reduce $\mathrm{SO}_{\mathrm{x}}, \mathrm{NO}_{\mathrm{x}}$ and $\mathrm{PM}$ emissions from ship exhaust gases in worldwide and establish Emission Control Areas (ECA) and/or Sulphur Emission Control Areas (SECA) (IMO 2015a). Under the Annex VI, ECA can be declared for $\mathrm{NO}_{\mathrm{x}}, \mathrm{SO}_{\mathrm{x}}$ and PM, and SECA can be declared for only $\mathrm{SO}_{\mathrm{x}}$. Existing ECA and SECA are listed below;

Baltic Sea (SOx ,19 May 2005)

North Sea and English Channel (SOx, 22 November 2007)

North American (NOx, SOx, PM, 1 August 2012).

US Caribbean (NOx, SOx, PM, 1 January 2014)(Raetsmarine 2013).

Turkey has carried out "the European Union IPA Twinning Project for the Control of Ship-Sourced Emissions in Turkey" to specify an ECA in the Sea of Marmara and Turkish Straits. After establishing ECA in Turkey, all ships passing through the Sea of Marmara and Turkish Straits have to meet the allowed limits of $\mathrm{SO}_{\mathrm{x}}$, $\mathrm{NO}_{\mathrm{x}}$ and PM emissions according to Annex VI of Marpol.

\subsection{Sulphur Oxides $\left(\mathrm{SO}_{x}\right)$ Reduction Methods}

Sulphuric gases become partially sulphate in the troposphere and lower stratosphere and form sulphuric acid also known sulphur oxides $\left(\mathrm{SO}_{\mathrm{x}}\right.$ ) (Ling 2011). Sulphur dioxide resulting from the combustion of fuels in many parts of the world is the main component of air pollution (WHO 2006). Other important sources of $\mathrm{SO}_{2}$ are electric utilities and industrial processes. Intensifying asthma and increasing respiratory symptoms are its health effects. WHO allowed $50 \mu \mathrm{g} / \mathrm{m}^{3}$ (year) limit and this limit is $250 \mu \mathrm{g} / \mathrm{m}^{3}$ (year) in Turkey (Peksen 2013).

$\mathrm{SO}_{\mathrm{x}}$ emissions limits were clarified in worldwide and ECA at MARPOL Annex VI Regulation 14 Sulphur oxides (SOx). Under MARPOL Annex VI, the global sulphur cap will be reduced from current $3.50 \% \mathrm{~m} / \mathrm{m}$ 
sulphur or $14 \mathrm{~g} \mathrm{SO}_{\mathrm{x}} / \mathrm{kWh}$ to $0.50 \%$ sulphur or $2 \mathrm{~g} \mathrm{SO}_{\mathrm{x}} / \mathrm{kWh}$, effective from 1 January 2020 , subject to a feasibility review to be completed no later than 2018. The limits applicable in ECAs for $\mathrm{SO}_{\mathrm{x}}$ were reduced to $0.10 \%$ sulphur or $0.4 \mathrm{~g} \mathrm{SO}_{\mathrm{x}} / \mathrm{kWh}$, from 1 January 2015 as mentioned in Table 1 (IMO official website 2015).

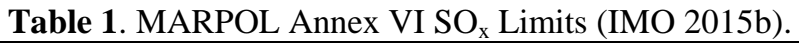

\begin{tabular}{|l|l|l|l|}
\hline Date & Worldwide & Date & ECA \\
\hline after 1 January 2012 & $\begin{array}{l}3.50 \% \mathrm{~m} / \mathrm{m} \mathrm{S} \text { or } 14 \mathrm{~g} \\
\mathrm{SO}_{\mathrm{x}} / \mathrm{kWh}\end{array}$ & after 1 July 2010 & $\begin{array}{l}1.00 \% \mathrm{~m} / \mathrm{m} \mathrm{S} \text { or } 4 \mathrm{~g} \\
\mathrm{SO}_{\mathrm{x}} / \mathrm{kWh}\end{array}$ \\
\hline after 1 January 2020 & $\begin{array}{l}0.50 \% \mathrm{~m} / \mathrm{m} \mathrm{S} \text { or } 2 \mathrm{~g} \\
\mathrm{SO}_{\mathrm{x}} / \mathrm{kWh}\end{array}$ & after 1 July 2015 & $\begin{array}{l}0.10 \% \mathrm{~m} / \mathrm{m} \mathrm{S} \text { or } 0.4 \mathrm{~g} \\
\mathrm{SO}_{\mathrm{x}} / \mathrm{kWh}\end{array}$ \\
\hline
\end{tabular}

For reduction of $\mathrm{SO}_{\mathrm{x}}$ emissions there are some alternative and suitable fuels and technologies such as MGO, LNG, biofules, nuclear fuel and scrubber. In this paper, MGO, LNG and Scrubber which are suitable alternatives have been analyzed.

MGO: One of the most viable options is MGO ( $0.1 \%$ sulphur content) in order to adapt SECA regulations, and also EU Sulphur Directive (2005/3/EC) for ship 'while berthing at EU ports' from 1 January 2010. MGO reduces not only $\mathrm{SO}_{\mathrm{x}}$ but also $\mathrm{PM}$ and $\mathrm{NO}_{\mathrm{x}}$ (if scrubber technology is used for $\mathrm{NO}_{\mathrm{x}}$ ), and that meets $\mathrm{NO}_{\mathrm{x}}$ limits under MARPOL Annex VI Regulation 13 Nitrogen Oxides (Adamchak and Adede 2013). Even though it is a clean fuel because of low sulphur content, it is an expensive fuel and increasing demand for these fuels may not be met by the existing petroleum refineries in the future.

Scrubber: As a gas cleaning technology, scrubber has been used since the 1930 s to remove $\mathrm{SO}_{2}$ from exhaust gases. This systems is commonly used in land-based industries, and there is no complexity and restrictions as a ship equipment (Bosch et al. 2009).

There are two basic types of scrubber system in ships for gas cleaning. One of them is working open loop sysem based on sea-water. Here, sea-water has a sufficient degree of alkalinity and naturally contains 900 mg per liter of sulphur, and it provides an optimal scrubbing factor. Therefore, it is excellent to capture and neutralize gases from exhaust emissions (Miola et al. 2010). The other type is called closed loop system based on fresh-water. In this system, the scrubber recycles freshwater in which caustic soda $(\mathrm{NaOH})$ is continuously added in order to balance $\mathrm{pH}$ at a little alkaline value and to clean exhaust emissions (Litehauz et al. 2012).

Consequently, scrubber technology can be used to fulfil the SECA requirements with range between 6594\% reduction performance. With this technology, $\mathrm{NO}_{\mathrm{x}}$ emission can be reduced $0-25 \%$ and PM emissions reduction performance is $65-95 \%$ (Kjølholt et al. 2012). Thus, scrubber might be a choise for ships to remain using low cost high sulphur fuel.

$\boldsymbol{L N G}$; Liquefied natural gas LNG) is fluid phase of intensified natural gas, and it contains a mixture of gases mostly by methane at least 90-95\% (Vandebroek and Berghmans 2012). LNG as a fuel has been used on gas carriers with boilers (in the case of steam turbine propulsion), four-stroke diesel mechanical propulsion or diesel electric propulsion installed for a long time, so using of LNG as a ship fuel is not a new idea. This concept depends on the consumption of available LNG cargo to use as the fuel in the LNG tankers (DNV and MAN Diesel\&Turbo 2011).

To use LNG as a fuel in ships, new engine technology for new building ships and retrofitting current engines for existing ships are well developed and available methods for ship owners/operators to meet environmental requirements ( $̊ F \& S S P A$ 2011). However, bunkering operations of LNG is still big problem for the maritime sector due to high costs of the required initial infrastructure investment such as special terminal, tanks and transferring system for LNG handling. Nowadays, there are three adopted ways for LNG bunkering. These methods are ship-to-ship bunkering, tank truck-to-ship bunkering, LNG intermediary terminal to-ship via pipeline (DMA 2012). Here, one of these methods can be chosen regarding needed LNG volume and that provides different solutions for users who will benefit from LNG fuel, and it is expected that LNG price will be cheaper than fuel oil in the future because of large reserves of natural gas in earth.

If LNG is used as a fuel in ships, it has a great positive impact on the environment and air quality by minimizing $\mathrm{SO}_{\mathrm{x}}, \mathrm{NO}_{\mathrm{x}}, \mathrm{PM}$ and $\mathrm{CO}_{2}$ emissions respectively $90-100 \%, 90 \%, 72 \%$ and $29 \%$ while comparing with oil based fuels (Tri-Zen International 2012; CNSS 2011). On the other hand, LNG may cause methane slip (Royal Academy of Engineering 2013). Table 2 summarizes these alternatives which can meet the $\mathrm{SO}_{\mathrm{x}}$ limit in ECA but cannot meet $\mathrm{NO}_{\mathrm{x}}$ limit except LNG. 
Table 2. Comparison of $\mathrm{SO}_{\mathrm{x}}$ emission reduction alternatives.

\begin{tabular}{|l|l|l|l|}
\hline & \multicolumn{1}{|c|}{ LNG } & \multicolumn{1}{c|}{ MGO } & \multicolumn{1}{c|}{ Scrubber } \\
\hline SO $_{\mathbf{x}}$ emission reduction & $90-95 \%$ & $0.10 \% \mathrm{~m} / \mathrm{m}^{*}$ & $65-94 \%$ \\
\hline Other emissions reduction & $\mathrm{NO}_{\mathrm{x}}, \mathrm{PM}, \mathrm{CO}_{2}$ & $\mathrm{NO}_{x}, \mathrm{PM}$ & $\mathrm{NO}_{\mathrm{x}}, \mathrm{PM}$ \\
\hline Investment cost & Very high & High & High \\
\hline Fuel price & Low & High & Very low \\
\hline Future supply & $\mathrm{High}$ & Low & High \\
\hline
\end{tabular}

*Content

\subsection{Nitrogen Oxides $\left(\mathrm{NO}_{x}\right)$ Reduction Methods}

Nitrogen Oxide $\left(\mathrm{NO}_{\mathrm{x}}\right)$ is a mixture of oxygen and nitrogen and is general term concerning air pollution for nitrogen monoxide $(\mathrm{NO})$ and nitrogen dioxide $\left(\mathrm{NO}_{2}\right)$ ( $\left.\mathrm{Ling} 2011\right)$. The major sources of nitrogen oxide emissions are as a result of human activities, the combustion process in stationary sources (heating, power generation) and movable sources (internal combustion engines on ships and vehicles) (WHO 2006). Nitrogen dioxide $\left(\mathrm{NO}_{2}\right)$ is the most harmful pollutant for human health; especially it is exacerbating lung diseases and augmenting susceptibility to respiratory infection (EPA 2012). Allowed limit of $\mathrm{NO}_{2}$ in EU $40 \mu \mathrm{g} / \mathrm{m}^{3}$ (year) and for Turkey this figure is $100 \mu \mathrm{g} / \mathrm{m}^{3}$ (year) (Peksen 2013). Maritime activities are an important source of $\mathrm{NO}_{\mathrm{x}}$ and their share is growing rapidly within other nitrogen sources (Cofala et al. 2007).

MARPOL Annex VI Regulation 13 aims to reduce $\mathrm{NO}_{x}$ emissions with different levels. These levels are called Tier. According to "Tier I", Marine diesel engines installed on a ship constructed on date between 1 January 1990 and 1 January 2000 are required to comply with "Tier I" emission limits. "Tier II" brings an emission limit for engines installed on a ship constructed on or after 1 January 2011 in worldwide; and a more stringent "Tier III" emission limit for engines installed on a ship constructed on or after 1 January 2016 while operating in ECAs (North American Emission Control Area and the U.S. Caribbean Sea Emission Control Area). The $\mathrm{NO}_{\mathrm{x}}$ control requirements of Annex VI implement to installed marine diesel engine of over $130 \mathrm{~kW}$ output power.

Table 3 summarizes Tier I, II and III (IMO 2015c).

Table 3. MARPOL Annex VI NO ${ }_{x}$ Emission Limits (IMO 2015c).

\begin{tabular}{|c|c|c|c|c|}
\hline \multirow[t]{2}{*}{ Tier } & \multirow[t]{2}{*}{$\begin{array}{l}\text { Ship construction } \\
\text { date on or after }\end{array}$} & \multicolumn{3}{|c|}{$\begin{array}{l}\text { Total weighted cycle emission limit }(\mathrm{g} / \mathrm{kWh}) \\
\mathrm{n}=\text { engine's rated speed }(\mathrm{rpm})\end{array}$} \\
\hline & & $\mathrm{n}<130$ & $\mathrm{n}=130-1999$ & $\mathrm{n} \geq 2000$ \\
\hline I & 1 January 2000 & 17.0 & $\begin{array}{l}45 \cdot \mathrm{n}^{(-0.2)} \\
\text { e.g., } 720 \mathrm{rpm}-12.1\end{array}$ & 9.8 \\
\hline II & 1 January 2011 & 14.4 & $\begin{array}{l}44 \cdot n^{(-0.23)} \\
\text { e.g., } 720 \mathrm{rpm}-9.7\end{array}$ & 7.7 \\
\hline III & 1 January $2016^{*}$ & 3.4 & $\begin{array}{l}9 \cdot \mathrm{n}^{(-0.2)} \\
\text { e.g., } 720 \mathrm{rpm}-2.4\end{array}$ & 2.0 \\
\hline
\end{tabular}

To meet the requirements of Annex VI NO limits, there are some alternative fuels and technologies such as LNG, Selective Catalytic Reduction (SCR), Humid Air Motors (HAM), Exhaust Gas Recirculation (EGR), Direct Water Injection (DWI) and Internal Engine Modifications (IEM). In this study only SCR, HAM methods which are more effective, economic and available than others have been analyzed.

Selective Catalytic Reduction (SCR): SCR system is the most effective and extensive technology for notable reduction of $\mathrm{NO}_{\mathrm{x}}$ emissions from diesel engines. SCR has been used widespread on highway and seaway i.e. over 300 ships achieve minimising $\mathrm{NO}_{\mathrm{x}}$ emissions by SCR (Lövblad and Fridell 2006). In the process of $\mathrm{SCR}$, firstly urea is injected into exhaust gas, secondly urea is converted to ammonia $\left(\mathrm{NH}_{3}\right)$, and then ammonia reacts with $\mathrm{NO}_{\mathrm{x}}$ in the SCR catalyst, and finally harmless nitrogen $\left(\mathrm{N}_{2}\right)$ and water $\left(\mathrm{H}_{2} \mathrm{O}\right)$ are obtained after this process (Lund 2010) 90\% reductions of $\mathrm{NO}_{\mathrm{x}}$ emissions have been achieved with SCR (ENTEC 2005). It does not require extra maintenance but requires extra space for ammonia storage (IAPH 2007).

Humid Air Motor (HAM): This technology is built on to use seawater in order to moisten the air by reducing the heat during the combustion process. As it is known, $\mathrm{NO}_{\mathrm{x}}$ emissions reduction performance is based on combustion temperature, because high temperature in the combustion chamber results $\mathrm{NO}_{\mathrm{x}}$ formation (Miola 2010). If three times larger water vapor than fuel is implemented into the engine, the system may reduce $\mathrm{NO}_{\mathrm{x}}$ emissions approximately 70-80\%; on the contrary, it does not contribute for reducing of other air pollutants emissions (ENTEC 2005).

Disadvantage of this technology is to need highest initial costs rather then other $\mathrm{NO}_{\mathrm{x}}$ emission reduction alternatives due to the integration requirement with the main engine (ENTEC 2005). 
Direct Water Injection (DWI): Injection of water to the engine changes the combustion temperature and properties of burned meterials in the cylinders based on rate of fuel-air mixture. This process impacts directly performance of parameters in combustion process and the formation of emissions (Ayhan 2009). DWI can reduce $\mathrm{NO}_{\mathrm{x}}$ emissions 50\% (ENTEC 2005). Investment cost of DWI is low for new building ships, however, retrofitting cost of current engine for DWI is very high in existing ships.

Exhaust Gas Recirculation (EGR): EGR means to re-circulate some of waste gases caused by fuel combustion back into cylinder in order to reburn (IAPH 2007). By this method, waste gases enter into the cylinder again instead of oxygen molecules. Thus, less $\mathrm{O}_{2}$ percentage in the cylinder decreases reaction speed and local flame temperature and finally reduces $\mathrm{NO}_{\mathrm{x}}$ emissions (Ayhan 2009). Although EGR has been used on four-stroke engines, it has not been commercially available for large two-stroke marine engines (DNV and MAN Diesel\&Turbo 2011). It reduces $\mathrm{NO}_{\mathrm{x}}$ emissions 35\%-50\% (ENTEC 2005; IAPH 2007) but it causes more fuel consumption. After comparing alternative technologies as shown in Table 4, it seems that SCR has the most effective performance to reduce $\mathrm{NO}_{\mathrm{x}}$ emissions in all. On the other hand, HAM seems the most cost effective systems for all type of engines in new building and existing ships. Therefore, only these three alternatives (LNG, SCR and HAM) have been analyzed in this study.

Table 4. Comparison of $\mathrm{NO}_{\mathrm{x}}$ emission reduction alternatives.

\begin{tabular}{|c|c|c|c|c|c|}
\hline & SCR & HAM & DWI & EGR & LNG \\
\hline $\mathrm{NO}_{\mathrm{x}}$ emission reduction & $90 \%$ & $70-80 \%$ & $50 \%$ & $35-50 \%$ & $90 \%$ \\
\hline Other emissions reduction & - & - & - & - & $\mathrm{SO}_{\mathrm{x}}, \mathrm{PM} \mathrm{CO}_{2}$ \\
\hline $\begin{array}{l}\text { Cost effective for new medium } \\
\text { vessel (Euro/ton } \mathrm{NO}_{\mathrm{x}} \text { abated) }\end{array}$ & 424 & 230 & 33 & 200 & - \\
\hline $\begin{array}{l}\text { Cost effective for existing } \\
\text { medium vessel (Euro/ton } \mathrm{NO}_{\mathrm{x}} \\
\text { abated) }\end{array}$ & 473 & 282 & - & - & - \\
\hline
\end{tabular}

\subsection{Study Area and Data}

The Sea of Marmara with the Istanbul and Çanakkale Straits is the only waterways connecting the Black Sea to the Aegean and Mediterranean Seas. Because of that, the vessels that sail from the Mediterranean Sea to the Black Sea or vice versa pass through the Istanbul and Canakkale Straits (Peksen 2013). Specific positions of Turkish Straits cause high vessel traffic, and also this high vessel traffic significantly increases air emissions on the Marmara Region. That result in deterioration of air quality, climate change and human health in this region where more than 20 million people live in. On the other hand, due to the problems based on air emissions Turkey has met external cost. Thus, Turkish Straits have been chosen as study area which is affected around 50,000 vessels' exhaust emissions in every year

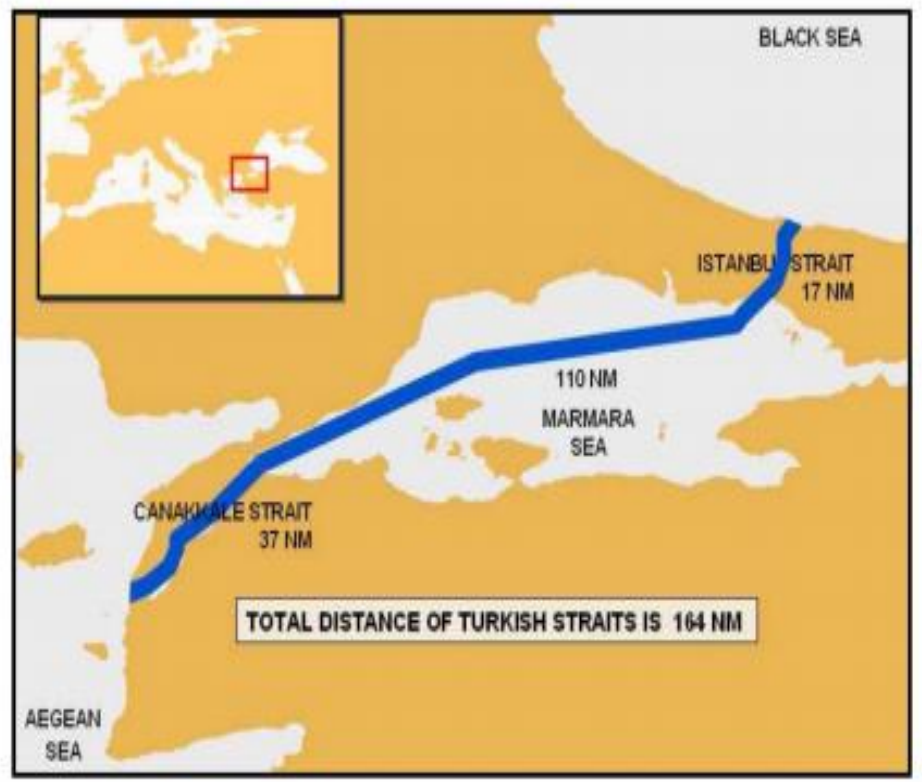

Figure 4. Maps of Turkish Straits (Turkish Straits Vessel Traffic Service (TSVTS) 2015).

As shown in Figure 4; the lenght of Çanakkale Strait, İstanbul Strait and the Sea of Marmara is 37, 17 and 110 nautical miles $(\mathrm{nm})$ respectively and in total $164 \mathrm{~nm}$. Information about vessels which are categorized by 
type and GT as shown in Table 5 has been received from Directorate General for Coastal Safety. In compliance with international merchant ships concept of the study, small ships' domestic traffic composed by ferries, fishing boats, recreational crafts and etc. sailing in the study area are excepted.

Table 5. Ship numbers sailing through Turkish Straits (Directorate General for Coastal Safety 2015).

\begin{tabular}{cccc}
\hline Ship Type & $\begin{array}{c}\text { Istanbul Strait } \\
(2014)\end{array}$ & $\begin{array}{c}\text { Canakkale Strait } \\
(2014)\end{array}$ & $\begin{array}{c}\text { Transit Passages } \\
(2014)\end{array}$ \\
\hline Bulk Carrier & 7,267 & 7,531 & 6,463 \\
\hline General Cargo & 24,107 & 17,297 & 11,493 \\
\hline Tanker ( Lpg) & 1,540 & 1,206 & 871 \\
\hline Passenger & 651 & 692 & 74 \\
\hline Tanker Chemical & 1,611 & 2,169 & 1,017 \\
\hline Tanker (product) & 5,594 & 5,875 & 4,477 \\
\hline Container Ship & 3,073 & 4,595 & 733 \\
\hline Other Type Ship & 1,686 & 4,217 & 1,084 \\
\hline Total Ship Numbers & $\mathbf{4 5 , 5 2 9}$ & $\mathbf{4 3 , 5 8 2}$ & $\mathbf{1 6 , 2 0 7}$ \\
\hline
\end{tabular}

\subsection{Calculating Ship Emissions by Ship Type or Fuel and Engine Type}

Emission can be estimated easily if these data are known: the installed main and auxiliary engine power, load factor and sailing time as in the following the Equation 1. This equation will be used to calculate the exhaust emissions caused by ships in the study area for the year 2014 (Trozzi 2010).

$E_{\text {trip i,p,s }}=\sum_{\mathrm{p}} D / N\left[M E x L F_{M E, p} x E F_{i, s, p}+A E x L F_{A E, P} x E F_{i, s, p}\right]$

$\mathrm{E}_{\text {trip }}$ : Emission over a complete trip (gram),

p: Phase of trip (cruise),

i: Pollutant $\left(\mathrm{NO}_{\mathrm{x}}, \mathrm{SO}_{\mathrm{x}}, \mathrm{CO}_{2}, \mathrm{PM}\right)$,

s: Ship type.

D: Distance $(\mathrm{km})$,

V: Velocity ( $\mathrm{km} / \mathrm{hour})$

ME: Main Engine $(\mathrm{kW})$

AE: Auxilalry Engine $(\mathrm{kW})$

$\mathrm{EF}$ : Emission factor $(\mathrm{g} / \mathrm{kWh})$

On the other hand, if the fuel and engine type is knwon, amount of ship emissions can be estimated with another method by using the Equation 2 which includes annual main and auxilary engine power hours, load factor and emission factors in accordance with the type of engine and consumed fuel during sailing. It is assumed that all ships in the study area use only MGO or HFO. This equation will be used to calculate total amount of emissions caused by these ships.

$E_{\text {trip f,e,i,p }}=\sum_{\mathrm{p}} D / V\left[M E x L F_{M E, p} x E F_{f, e, i, p}+A E x L F_{A E, P} x E F_{f, e, i, p}\right]$

p: Phase of trip (cruise),

f: Fuel type (MGO, HFO)

e: Engine type (SSD, MSD, ST).

i: Pollutant $\left(\mathrm{NO}_{\mathrm{x}}, \mathrm{SO}_{\mathrm{x}}, \mathrm{CO}_{2}, \mathrm{PM}\right)$,

\subsection{External Costs}

Under $6^{\text {th }}$ framework programme of the European Union (EU) "A New Environmental Accounting Framework Using Externality Data and Input-Output Tools for Policy Analysis" (EXIOPOL) aims to define theoretical-mathematical concepts of linking environmental extensions (EE) to the framework of Supply-and Use-Tables (SUT) for 43 countries (including Turkey). EXIOPOL also use emission data of each state (EXIOPOL 2010).

To estimate external cost caused by ship emissions for Turkey, the result of emission calculations and EXIOPOL projects' factors as shown in Table 6 have been used. 
Table 6. External cost factors per ton for transport ( Euro $_{2014 /}$ ton).

\begin{tabular}{cccc}
\hline & Human Health & Ecosystem Quality & Total \\
Pollutant & & & \\
\hline $\mathbf{S O}_{\mathbf{2}}$ & 8168 & 259 & 8.427 \\
\hline $\mathbf{N O}_{\mathbf{x}}$ & 7390 & 1.296 & 8.686 \\
\hline $\mathbf{P M}$ & 453751 & 0 & 453.751 \\
\hline
\end{tabular}

Inflation over the period: $29.64 \%$ (http://fxtop.com/en/inflation-calculator.php)

\section{RESULTS AND DISCUSSION}

The answers of the questions in the introduction are found by made some calculation with the help of the above equations and ship information. Approximate amount of ship emissions in current case and in study case while using alternative fuel and technology instead of existing engine systems have been calculated and compared with each other as shown in Figure 5, 6, 7 and 8 respectively.

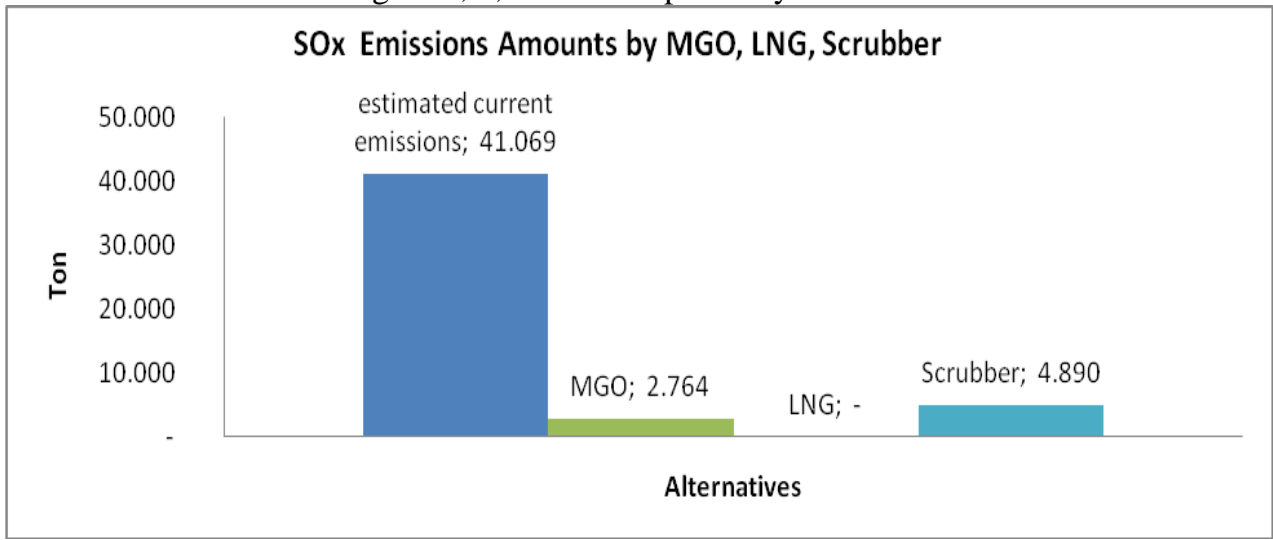

Figure 5. $\mathrm{SO}_{\mathrm{x}}$ emission amounts in different cases (ton).

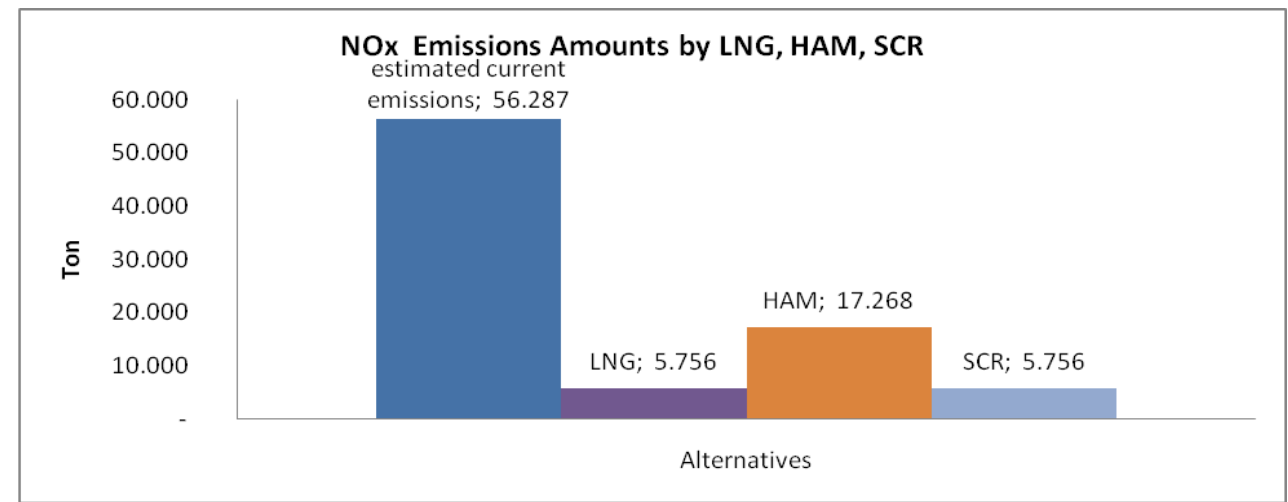

Figure 6. $\mathrm{NO}_{\mathrm{x}}$ emission amounts in different cases (ton).

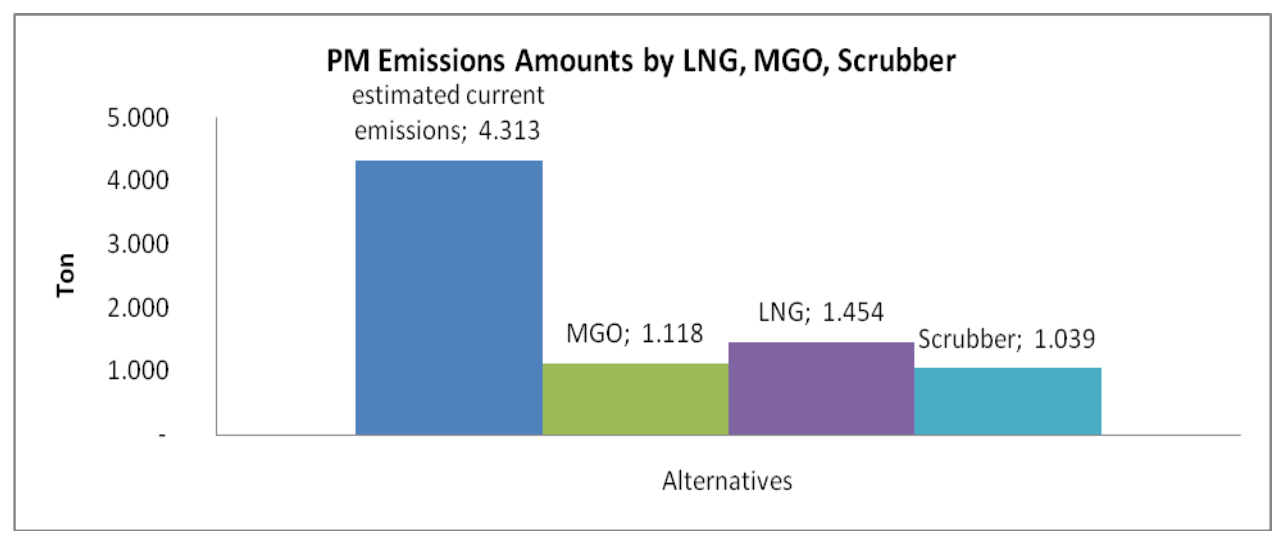

Figure 7. PM emissions amount in different cases (ton). 


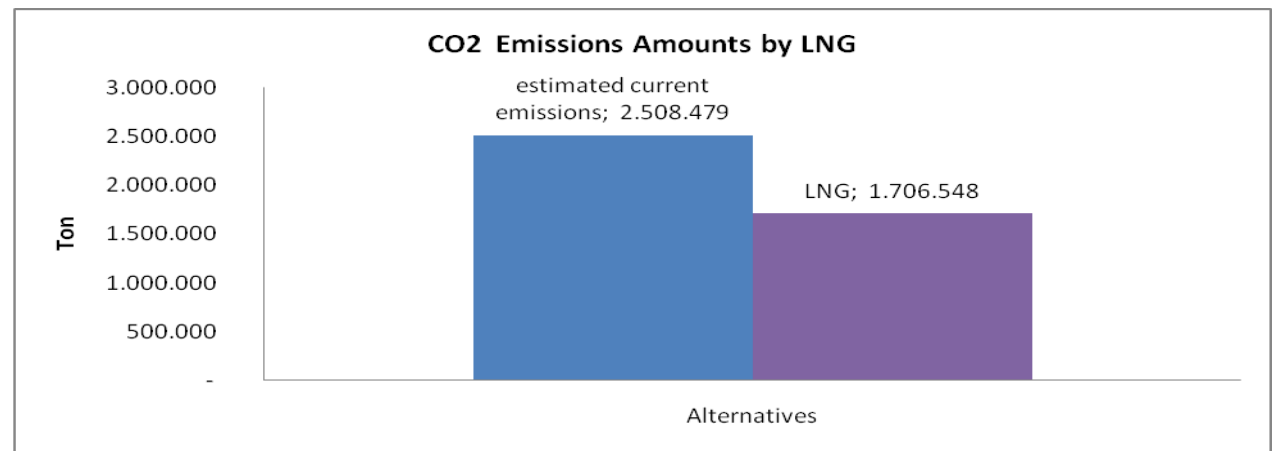

Figure 8. $\mathrm{CO}_{2}$ emissions amount in different cases (ton).

External costs of $\mathrm{SO}_{\mathrm{x}}, \mathrm{NO}_{\mathrm{x}}$ and $\mathrm{PM}$ after the alternatives came into effect have been calculated as shown in Table 7 according to previous findings referred to Figures 5-8.

Table 7. External costs in different cases (Euro).

\begin{tabular}{|c|c|c|c|c|}
\hline Cases & Emission & $\mathrm{SO}_{2}$ & $\mathbf{N O}_{\mathrm{x}}$ & Total \\
\hline \multirow{2}{*}{ Current Case } & $\begin{array}{l}\text { Human } \\
\text { Health }\end{array}$ & $335,452,034$ & $415,957,746$ & \multirow[t]{2}{*}{ 834.994.058 } \\
\hline & $\begin{array}{c}\text { Ecosystem } \\
\text { Quality }\end{array}$ & $10,636,885$ & $72,947,394$ & \\
\hline \multirow{2}{*}{ MGO } & $\begin{array}{l}\text { Human } \\
\text { Health }\end{array}$ & $22,576,597$ & $359,334,241$ & \multirow{2}{*}{ 445.643.931 } \\
\hline & $\begin{array}{c}\text { Ecosystem } \\
\text { Quality }\end{array}$ & 715,884 & $63,017,209$ & \\
\hline \multirow{2}{*}{ LNG } & $\begin{array}{c}\text { Human } \\
\text { Health }\end{array}$ & 0 & $42,537,110$ & \multirow[t]{2}{*}{ 49.996.933 } \\
\hline & $\begin{array}{c}\text { Ecosystem } \\
\text { Quality }\end{array}$ & 0 & $7,459,823$ & \\
\hline \multirow{2}{*}{ SCR } & $\begin{array}{c}\text { Human } \\
\text { Health }\end{array}$ & $332,867,881$ & $42,537,110$ & \multirow[t]{2}{*}{ 393.419.757 } \\
\hline & $\begin{array}{c}\text { Ecosystem } \\
\text { Quality }\end{array}$ & $10,554,944$ & $7,459,823$ & \\
\hline \multirow{2}{*}{ HАM } & $\begin{array}{c}\text { Human } \\
\text { Health }\end{array}$ & $332,867,881$ & $127,611,329$ & \multirow[t]{2}{*}{ 493.413.623 } \\
\hline & $\begin{array}{c}\text { Ecosystem } \\
\text { Quality }\end{array}$ & $10,554,944$ & $22,379,470$ & \\
\hline
\end{tabular}

\section{CONCLUSION}

Ship traffic in the Turkish Straits, which has the international strategic importance, was over 45,000 in 2014. When this area is declared as ECA, shipowners and/or operators must obey of the rules for releasing low sulphur and nitrogen from their ships. This situation seriously improves the country's air quality and provides environmental benefits. The fact that it will assist to prevent air pollution and acid rains, therefore, ECA obviously provides economic benefits from the external cost saving by decreasing health expenditures and increasing productivity of the agricultural activities in the Marmara Region.

\section{NOTE: THIS ARTICLE WAS PRESENTED AT INTERNATIONAL CONFERENCE ON CIVIL AND ENVIRONMENTAL ENGINEERING ICOCEE - CAPPADOCIA 2015 Nevsehir, TURKEY, May 20- 23, 2015}

\section{REFERENCES}

[1] Abusoglu A and Kanoglu M (2009) Dizel Motorlu Kojenerasyon Sistemlerinin Emisyon Özelliklerinin İncelenmesi, Isı Bilimi ve Tekniği Dergisi, 29, 1, 45-53, 2009

[2] Adamchak F and Adede A (2013) LNG as Marine Fuel, 17th International Conference \& Exhibition On Liquefied Natural Gas (LNG 17), Houston.

[3] ÅF\&SSPA (2011) North pean LNG Infrastructure Project: A feasibility Study for an LNG Filling Station Infrastructure and Test of Recommendations, Baseline Report, Danish Maritime Authority \& Mogens Schroder Bech. 
[4] Ayhan V (2009) Bir Dizel Motoruna Buhar Enjeksiyonunun NO ve Is Emisyonlarına Etkisinin Araştırılması, Doktora Tezi, Fen Bilimleri Enstitüsü.

[5] Bosch P, Coenen P, Fridell E, Åström S, Palmer T, Holland M (2009) Cost Benefit Analysis to Support the Impact Assessment Accompanying the Revision of Directive 1999/32/EC on the Sulphur Content of Certain Liquid Fuels, Report to pean Commission, AEA Technology, UK, ED45756, Issue 3.

[6] CNSS (2011) A Review of Present Technological Solutions for Clean Shipping, http://cnss.no/wpcontent/uploads/2011/10/Summary-brochure10.pdf

[7] Cofala J, Amann M, Heyes C, Wagner F, Klimont Z, Posch M, Tarasson WSL, Jonson JE, Whall C, Stavrakaki A, (2007) Analysis of Policy Measures to Reduce Ship Emissions in the Context of the Revision of the National Emissions Ceilings Directive, IIASA, Austria

[8] Directorate General for Coastal Safety (2015).

[9] DMA (2012) North pean LNG Infrastructure Project: A feasibility study for an LNG filling station infrastructure and test of recommendations Full Report, March 2012, Copenhagen.

[10] DNV and MAN Diesel\&Turbo (2011) Quantum 9000 Two Stroke LNG, http://marine.man.eu/docs/librariesprovider6/technical-papers/quantum-9000.pdf?sfvrsn=18

[11] ENTEC (2005) Service Contract on Ship Emissions: Assignment, Abatement and Market-based Instruments, Task $2 b-\mathrm{NO}_{x}$ Abatement, pean Commission Directorate General Environment, August 2005, Entec UK Limited.

[12] EPA (2012) Our Nation's Air Status and Trends Through 2010, February 2012

[13] http://www.epa.gov/airtrends/2011/report/fullreport.pdf

[14] EXIOPOL (2010) “A New Environmental Accounting Framework Using Externality Data And InputOutput Tools For Policy Analysis, Final report providing external cost values to be applied in an EE SUT framework”, March 2010, PROJECT N. 037033.

[15] IAPH (2007) Tool Box For Port Clean Air Programs Improving Air Quality While Promoting Business Development, December 2007.

[16] IMO official website (2015a ) http://www.imo.org/OurWork/Environment/PollutionPrevention/AirPollution/Pages/Air-Pollution.aspx

[17] IMO official website (2015b) http://www.imo.org/OurWork/Environment/PollutionPrevention/AirPollution/Pages/Sulphur-oxides(SOx)-\%E2\%80\%93-Regulation-14.aspx

[18] IMO official website (2015c) http://www.imo.org/OurWork/Environment/PollutionPrevention/AirPollution/Pages/Nitrogen-oxides(NOx)-\%E2\%80\%93-Regulation-13.aspx

[19] Inflation calculator website (2015) http://fxtop.com/en/inflation-calculator.php

[20] Jalkanen J.P, Effect of Baltic NECA on Ship $N O_{x}$ Emissions, BSR Innoship, Finnish Meteorological Institute

[21] Kjølholt J, Aakre S, Jürgensen C, Lauridsen J (2012) Assessment of Possible Impacts of Scrubber Water Discharges on the Marine Environment, Environmental Project No. 1431, Miljøstyrelsen, ISBN 978-8792903-30-3.

[22] Ling JTL (2011) Air Emissions: the Effects on the Shipping Industry and Ports Implications for the Port of Singapore, MS.c, World Maritime University, Malmö.

[23] Litehauz, Lack DA, Thuesen J, Elliot R, Erria DK (2012) Investigation of Appropriate Control Measures (abatement technologies) to Reduce Black Carbon Emissions from International Shipping .

[24] Lund KT (2010) Cleaner Reduction of $\mathrm{NO}_{\mathrm{x}}$ Emissions from Shipping, Shipping Conference, Copenhagen November 29th 2010.

[25] Lövblad G and Fridell E (2006) Experiences from Use of Some Techniques to Reduce Emissionsfrom Ships, Gothenburg: Profu, IVL Svenska Miljöinstitutet.

[26] Miola A, Ciuffo B, Giovine E, Marra M (2010) Regulating Air Emissions from Ships The State of the Art on Methodologies, Technologies and Policy Options, Publications Office of the pean Union Publications, Italy, ISBN 978-92-79-17733-0.

[27] Mueller D, Uibel S, Takemura M, Klingelhoefer D and Groneberg DA (2011) Ships, ports and particulate air pollution - an analysis of recent studies, Journal of Occupational Medicine and Toxicology, 2011 6:31, DOI:10.1186/1745-6673-6-3

[28] Peksen NH, (2013) A New Approach for Turkish Ports to Reduce Ship Emissions Case Study: Application of Cold Ironing System for Marport Container Terminal with Investment Analysis, MS.c, World Maritime University, Malmö.

[29] Raetsmarine (2013) Emission Control Areas (ECA) Developments, Circular, raetsmarine.com.

[30] Royal Academy of Engineering (2013) Future Ship Powering Options Exploring Alternative Methods of 
Ship Propulsion, Royal Academy Of Engineering, July 2013.

[31] Schrooten L, Vlieger ID, Panis LI, K. Styns, Torfs R (2007) Inventory And Forecasting of Maritime Emissions in The Belgian Sea Territory, an Activity-Based Emission Model, Atmospheric Environment ,42 (2008) 667-676.

[32] T.C. Başbakanlık Mevzuat Bilgi Sistemi http://www.mevzuat.gov.tr

[33] Tri-Zen International (2012) The Genesis of LNG Bunkers, LNG Markets Perspective, January 2012.

[34] Trozzi (2010) Emission Estimate Methodology for Maritime Navigation, US EPA 19th International Emissions Inventory Conference, 09/2010.

[35] Turkish Straits Vessel Traffic Service (TSVTS) Official Webpage, http://www.afcan.org/dossiers_techniques/tsvts_gb.html

[36] United States Environmental Protection Agency offical website (2015)

[37] http://www.epa.gov/climatechange/ghgemissions/gases.html

[38] Vandebroek L, and Berghmans J (2012) Safety Aspects of the Use of LNG for Marine Propulsion, 2012 International Symposium on Safety Science and Technology, Procedia Engineering 45 (2012) 21-26.

[39] Varınca KB, Güneş G, Ertürk F. Hava Kirleticilerinin İnsan Sağllğg ve İklim Değişikliği Üzerine Etkileri, Çevre Mühendisliği Bölümü, http://www.yildiz.edu.tr/ kvarinca/Dosyalar/Yayinlar/yayin020.pdf

[40] WHO (2006) Air Quality Guidelines Global Update 2005, WHO Regional Office, Denmark, ISBN 92 89021926. 